\title{
Potential allelopathic and antibacterial activity from Alternanthera philoxeroides ${ }^{1}$
}

\author{
Alítcia Moraes Kleinowski ${ }^{2,4}$, Gládis Aver Ribeiro ${ }^{3}$, Cristini Milech ${ }^{2}$ and Eugenia Jacira Bolacel Braga ${ }^{2}$ \\ Received: 11.04.2016; accepted: 13.09.2016
}

\begin{abstract}
Potential allelopathic and antibacterial activity of Alternanthera philoxeroides). Alternanthera philoxeroides is a promising species in the search for new molecules with biological effects. To accelerate this bioprospection process of $A$. philoxeroides, the chosen methods (allelopathy and discdiffusion technique) are excellent alternatives. The purpose of this study was to evaluate the allelopathic effects and verify the antibacterial properties of extracts from $A$. philoxeroides. To evaluate the antibacterial activity, disc diffusion technique was used with five reference strains. The germination test was conducted with the extracts at concentrations of $0,1.0,2.0$ e $3.0 \mathrm{mg} \mathrm{mL}^{-1}$ in a petri dish with 30 lettuce seeds and for the growth trial 10 seeds were used. The experimental design was completely randomized in factorial $4 \times 2 \times 4$ (four extracts, two sources, four concentrations), with four replicates. The results indicate that the lettuce germination was influenced by ethyl acetate fraction obtained from leaves of A. philoxeroides at the highest concentrations; however, the germination speed and the radicle growth were significantly affected by all the extracts starting at $1 \mathrm{mg} \mathrm{mL}-1$ concentration. Those results demonstrate allopathic effect of different extracts of this plant, although they have not interfered with the strains growth used in this experiment.
\end{abstract}

Keywords: alellopathy, alligator weed, disc diffusion, germination

RESUMO - (Potencial alelopático e atividade antibacteriana de Alternanthera philoxeroides). Alternanthera philoxeroides é uma espécie promissora na busca de novas moléculas com efeitos biológicos. Para acelerar este processo, os métodos de escolha, tal como o teste de alelopatia em sementes e técnica de disco de difusão em bactérias, é indispensável. O objetivo deste estudo foi avaliar os efeitos alelopáticos de extratos de A. philoxeroides e verificar as propriedades antibacterianas desta planta. Os extratos foram obtidos por líquido-líquido e para avaliar a atividade antibacteriana foi utilizada técnica de difusão de disco com cinco estirpes de referência. $O$ teste de germinação foi realizada com os extratos em concentrações de $0,1,0,2,0$ e 3,0 $\mathrm{mg} \mathrm{mL}^{-1}$ feitos em placa de Petri com 30 sementes de alface e o ensaio de crescimento foi utilizado 10 sementes. O delineamento experimental foi inteiramente casualizado em fatorial $4 \times 2 \times 4$ (quatro extratos, duas fontes, quatro concentrações, resultando em 32 tratamentos), cada um com quatro repetições. Os resultados indicam que a germinação de sementes de alface foi influenciada pela fração de acetato de etila obtida a partir de folhas de $A$. philoxeroides na maior concentração, no entanto, o crescimento radicular de sementes de alface foi afetado por todos os extratos a partir de $1 \mathrm{mg} \mathrm{mL}^{-1}$. Esses resultados demonstram efeito alopático de diferentes extratos desta espécie, mas nenhum dos extratos de A. philoxeroides nas concentrações testadas interferiu com o crescimento das estirpes utilizadas.

Palavras-chave: alelopatia, disco difusão, erva- de-jacaré, germinação

\section{Introduction}

The natural products obtained from plants are investigated and used by the human beings, many times, empirically to relieve their diseases, since the beginning of history. Before the "synthesis age" in $1950,80 \%$ of all the medicines utilized were obtained from root, stem and leaves of plants (Mcchesney et al. 2007).

The wealth of the Brazilian flora associated with the ethnobotanical and pharmacognostical survey allow the researchers to isolate biologically active compounds from different plant species, which can evolve into models both for medicine synthesis and

1. Parte da Dissertação de Mestrado do primeiro Autor

2. Universidade Federal de Pelotas, Instituto de Biologia, Departamento de Botânica, Laboratório de Cultura de Tecidos de Plantas, 96010-610 Pelotas, RS, Brasil

3. Universidade Federal de Pelotas, Departamento de Microbiologia e Parasitologia, Laboratório de Bacteriologia, 96010-610 Pelotas, RS, Brasil

4. Corresponding author: amk_bio@hotmail.com 
for products of agricultural or forest application (Guerra \& Nodari 2001).To explain the importance of the phytochemical studies and medicinal plants bioprospection, about half of all the medicines and/or agricultural products licensed and registered all over the world in the period previous to the year of 2010 , were natural products or their derivative synthetic products (Dias et al. 2012). Nevertheless, taking into consideration the vast Brazilian biodiversity and heterogeneity of the active metabolites of those plants, a plenty of molecules still need to be discovered and better identified.

Amidst the Brazilian flora, the species Alternanthera philoxeroides, genus Alternanthera (Amaranthaceae), known popularly as alligatorweed, deserves to be pointed out, due to the fact that phytochemical prospections of the same have revealed a variety of biologically active compounds, among them the triterpenoids, flavonoids and betalains (Sousa et al. 2008; Brochado et al. 2003) Those compounds possess comproved antitumoral, antiviral (Fang et al. 2009), anti-inflammatory and immunomodulatoryactions (Salvador \& Dias 2004) being, therefore, a promising material for the search of new molecules with biological effects. To accelerate that process, the choice of simple, sensitive, practical and reliable methods, which eliminate steps in the process of separation of bioactive constituents become indispensable (Cunico et al. 2006).

Allelopathy has been defined by the International Society of Allelopathy as processes which involve the production of secondary metabolites by plants and microorganisms which influence the growth and development of biological systems with positive and negative effects (Gonzáles et al. 2002, Pinto et al. 2002). Thus, allelopathy is accepted as an encompassing science, being able to be used in the control of diseases, microorganisms and weeds which compete against medicinal plants, providing highquality raw material for phytotherapic industry (Dias \& Miguel 2005).

The seed germination tests and initial radicle growth in the presence of medicinal plant extracts are of great scientific interest, since lots of allelochemicals are utilized in folk medicine for the treatment of several diseases. In addition, that interaction can be a source of discoveries of new natural phytotoxic compounds with low toxicity to the non-target control organisms (Dias et al. 2008).

The tolerance to secondary metabolites which act as allelochemicals is variable within the plant species, some being highly sensitive, regarded as bioindicators as, for instance, Lactuca sativa (lettuce), greatly utilized in laboratory biotests according to Ferreira \& Aquila (2000). Besides, another biological test utilized in the scope of molecules with biological properties and more precisely antimicrobials the Disc Diffusion technique which uses reference strains bacterias bioindicators (Nascimento et al. 2007).

A great part of antimicrobials in use (penicillin, cephalosporins, aminoglycosides, among others) are derived from secondary fungi and bacteria metabolites, nevertheless, the antimicrobial properties of those metabolites, present in both extracts and essential oils of plants, in the future, can replace the medicines formerly efficient, derived from microorganisms (Duarte, 2006).

This way, the investigation of antibacterial potential molecules in the genus Alternanthera is quite relevant since those species possess a huge structural diversity of their natural products; in addition, some promising studies were conducted in the search for molecules with this biological activity (Jalapure et al. 2008, Jandrey \& Onofre 2009, Facundo et al. 2012, Kannan et al. 2014). Based on this information, the objective of the present work was to carry out studies to evaluate the allelopathic effects and the antibacterial capacity of the extracts of stems and leaves of $A$. philoxeroides.

\section{Material and methods}

The work was conducted in the Plant Tissue Culture Laboratory of the Department of Botany/ IB-UFPel and in the Bacteriology Laboratory of the Microbiology and Parasitology Department/IB of the UFPel.

Plants of A. philoxeroides (Mart.) Grisebach (alligatorweed) were collected in the city of Rio Grande/RS (June of 2006) and the identification was executedby the agronomist Élen Nunes Garcia and her exsiccates deposited in the Pelotas Federal University Botany Department Herbarium - RS under the number 24535. A. philoxeroides cultivated in vitro were acclimatized in greenhouse for 90 days with relative humidity of $80 \%$ and temperature between 18 and $23{ }^{\circ} \mathrm{C}$.

Preparation of the Extracts - Leaves and stems of A. philoxeroides were dried in forced ventilation oven for 10 days at $35^{\circ} \mathrm{C}$, powdered in knife mill and submitted, separately, to the cold soaking extraction with hydroalcoholic extract $(70 \%)$ at the proportion of 
1:1 ( $\mathrm{m} / \mathrm{v})$ for seven days. The extracts were filtered and $100 \mathrm{~mL}$ out of these were collected for obtaining of a crude extract (EB). With the remaining extract, liquidliquid portioning with solvents of growing polarities (hexane, dichloromethane, ethyl acetateand butanol) of the Sigma ${ }^{\circledR}$ mark was carried out. The fractions and the EB were concentrated into a rotary evaporator, under reduced pressure to its total drying, according to methodology described by Cechinel \& Yunes (1998). The dry extracts were dissolved again in distilled water obtaining solutions at concentrations of 1.0, 2.0 and $3.0 \mathrm{mg} \mathrm{mL}^{-1}$ and distilled water as the control.

Germination inhibition and initial growth of the radicle (allelopathy) - The germination and growth tests were conducted on Petri plates $9.0 \mathrm{~cm}$ diameter, containing two filter papers and $4.0 \mathrm{~mL}$ of each extract 30 lettuce seeds (Lactuca sativa L.) per plate were sown and next, the plates were taken to the BOD at the temperature of $20^{\circ} \mathrm{C}$ and $12 \mathrm{~h}$ photoperiod for the germination tests. The growth tests were performed under these same conditions, nevertheless, 10 seeds on each plate were sown. For the dormancy braking, the lettuce seeds utilized were previously submitted to cooling of $4{ }^{\circ} \mathrm{C}$ for $72 \mathrm{~h}$ (MAPA 2009).

The germination rate was checked every 24 hours for seven days, using the root protrusion as a criterion for germinability. The following variables were determined: First Count (PC), Germination (G), Germination Speed Index (IVG) and Radicle Length, according to the Rules for Seed Analysis (MAPA 2009).

All treatments were arranged in a completely randomized design in factorial scheme $4 \times 2 \times 4$ (four types of extracts, two organs and four extract concentrations) resulting into 32 treatments with four replications. The results were submitted to the analysis of variance and means compared by the Tukey test (5\%) with the support of Winstat software, 2002 (Machado \& Conceição 2002).
Antibacterial activity - The evaluation of the antibacterial activity was carried out with the organic extracts and EB ressolubilized in dimethylsulfoxide (DMSO), standardized at the concentration of $100 \mathrm{mg} \mathrm{mL}^{-1}$ on account of the maximum yield being obtained from all the extracts through Disk Diffusion Technique. It was evaluated five reference strains, Bacillus cereus, Staphylococcus aureus (ATCC 25923), Bacillus subtilis, Pseudomonas aeruginosa (ATCC 9027) and Escherichia coli (ATCC 8739), belonging to the Bacteria Collection Bacteriology Laboratory of the Department of Microbiology and Parasitology Institute of Biology UFPel. The strains were kept in conservation-agar and before the tests, they were recovered in Agar Brain Heart Infusion (BHI - Acumedia ${ }^{\circledR}$ ) and incubated for $24 \mathrm{~h}$ at $36^{\circ} \mathrm{C}$.

In the disc diffusion technique, the bacterial inoculum, standardized at the concentration of $1,5 \times 10^{8} \mathrm{UFC} \mathrm{mL}^{-1}$, were spread on the surface of the Mueller-Hinton agar culture medium. Afterwards, sterile filter paper disks six millimeters in diameter soaked of the extracts, DMSO (negative control) and chloramphenicol (positive control) were arranged on the plates, which were then next, incubated at $36{ }^{\circ} \mathrm{C}$ for 24 hours. The experiment was done in triplicate for each bacterial strain and the reading of the results was conducted by checking either the presence or absence of inhibition halos.

\section{Results and Discussion}

Inhibition of the radicle germination and growth - For the variable first count of germination, there was significant interaction between concentration of the extracts and types of solvents utilized, whereby the ethyl acetate extract at the highest concentration was the one which presented negative influence in this variable (table 1).

Table 1. First count of germination of lettuce seeds submitted to different concentrations and types of extracts of Alternanthera philoxeroides.

\begin{tabular}{ccccc}
\hline & \multicolumn{4}{c}{ First count $(\%)$} \\
\cline { 2 - 4 } Concentration of the extracts $\left(\mathrm{mg} \mathrm{L}^{-1}\right)$ & Hexane & Ethyl acetate & Butanolic & Aqueous \\
\cline { 2 - 4 } & $100 \mathrm{Aa}$ & $100 \mathrm{Aa}$ & $100 \mathrm{Aa}$ & $100 \mathrm{Aa}$ \\
0 & $100 \mathrm{Aa}$ & $98.5 \mathrm{Aa}$ & $100 \mathrm{Aa}$ & $100 \mathrm{Aa}$ \\
2 & $100 \mathrm{Aa}$ & $98.2 \mathrm{Aa}$ & $100 \mathrm{Aa}$ & $100 \mathrm{Aa}$ \\
3 & $100 \mathrm{Aa}$ & $96.5 \mathrm{Bb}$ & $100 \mathrm{Aa}$ & $99.0 \mathrm{Aa}$ \\
\hline
\end{tabular}

*Means followed by the same capital letters in the column and small ones in the row do not differ statistically by the Tukey test at the level of $5 \%$ of error probability. 
These results are similar to those observed by Dias et al. (2007), who studying the effect of crude extract and fractions hexane, methylene chloride and ethyl acetate of stems, leaves and flowers of Aster lanceolatus in lettuce seeds, found that the ethyl acetate extract of stems and leaves adversely affected the response of the first count test.

With the use of liquid-liquid partitioning methodology described by Cechinel \& Yunes (1998), the ethyl acetate fraction may conduct large part of the phenolic compounds present in the crude extract. Those phenolic molecules are known for their inhibiting germination power, since many of these compounds act at the cellular level and on the plasma membrane causing the interruption of a range of cellular processes with the release of reactive oxygen species (ROS) (Eldeen et al. 2006). Furthermore, they are capable of inhibiting the action of gibberellins, either by interaction with the molecule or by blocking the process mediated by them, as a reduction in the synthesis of hydrolytic enzymes such as amylase and acidphosphatase in the endosperm of seeds, thus hindering germination process (Sampietro 2001).
Still for first count there was significant interaction between the concentration of the extracts and the types of organs from which they were obtained, where by the leaf extract at the highest concentration was the one which presented significant difference (table 2).

In studies comparing the inhibitory effect on the basis of the source of Ateleia glazioveana Baill extract on lettuce seeds, it was observed that the aqueous extracts coming from the leaves caused inhibitory effects superior to those of the stem (Anese et al. 2007).

For the variable germination there was significant interaction between types of organs utilized and the extraction solvent, considering that the ethyl acetate extract obtained from the leaves, was the one which influenced this variable causing reduction in germination when compared to other extracts (table 3 ).

The phenolic molecules extract by this kind of solvent, possibly, it's a responsible for that effect, as described by Cechinel \& Yunes (1998) and similar to occurred in the first germination count. In this work the crude extract, obtained through soaking, in none of the tested concentrations a negative effect on

Table 2. First count of lettuce seed germination submitted to different types of extraction solvents and organs of Alternanthera philoxeroides.

\begin{tabular}{lcc}
\hline \multirow{2}{*}{ Extraction solvents } & \multicolumn{2}{c}{ First count (\%) } \\
\cline { 2 - 3 } & Source organs \\
\hline Hexane & Leaf & Stem \\
Ethyla acetate & $100 \mathrm{Aa}$ & $100 \mathrm{Aa}$ \\
Butanolic & $96.5 \mathrm{Bb}$ & $100 \mathrm{Aa}$ \\
Aqueous & $100 \mathrm{Aa}$ & $100 \mathrm{Aa}$ \\
\hline
\end{tabular}

**Means followed by the same capital letters in the column and small ones in the row do not differ statistically by the Tukey test at the level of $5 \%$ of error probability.

Table 3. Germination of lettuce seeds submitted to different types of extraction solvents and organs of Alternanthera philoxeroides.

\begin{tabular}{lcc}
\hline & \multicolumn{2}{c}{ Germination (\%) } \\
\cline { 2 - 3 } Extraction solvents & \multicolumn{2}{c}{ Source organs } \\
\cline { 2 - 3 } & $100 \mathrm{Aa}$ & stem \\
\hline Hexane & $97.2 \mathrm{Bb}$ & $100 \mathrm{Aa}$ \\
Ethyl acetate & $100 \mathrm{Aa}$ & $100 \mathrm{Aa}$ \\
Butanolic & $99.75 \mathrm{Aa}$ & $100 \mathrm{Aa}$ \\
Aqueous & & $100 \mathrm{Aa}$ \\
\hline
\end{tabular}

*Means followed by the same capital letters in the column and small ones in the row do not differ statistically by the Tukey test at the level of $5 \%$ of error probability. 
germination was shown, contradicting the findings by Mairesse et al. (2007), who studying the bioactivity of different concentrations of aqueous extracts of Alternanthera brasiliana in lettuce seeds, found an inhibitory effect soon at the first concentration used $(25 \%)$, demonstrating thus, the allelopathic potential of this species.

Germination inhibition and initial radicle growth (allelopathy) - The germination speed index suffered significant influence from the different extraction solvents and from the source organs (table 4), of which the leaf extracts with ethyl acetate and stem with butanolic and aqueous solvent, were the ones which caused reduction in germination rate the most.

For the germination of the bioindicator seeds to occurin the treatments used, there must be detoxification of the substratewhere they were sown through evaporation or other processes, of the potentially alellochemical substances and that event causes changes in the distribution curve of germination, stretching it through time axis (Ferreira $\&$ Aquila 2000).
Regarding the concentrations of the extracts (table 5), taking into consideration all the solvents utilized, there was a significant interaction between both the factors, resulting into decreased germination speed of the bioindicator seeds with increasing concentration of the extracts, considering that at the highest concentration, the radicle protrusion speed was decreased.

The authors Ferreira \& Borghetti (2004), stand out that frequently the allelopathic effect does not occur through the germinability reduction (final percentage of germination), but it is about the germination speed which is decreased over time.

As to the length of the radicles, it may be observed that there was a significant interaction between the concentrations and the types of solvents utilized where all of the extracts originating at concentration of $1 \mathrm{mg} \mathrm{mL}-1$ differed statistically from the control, considering that at the highest concentration the lowest length radicle values were obtained (table 6). Those results demonstrate greater sensitivity of that variable to the deleterious effects of the allelochemicals present in the extracts of $A$. philoxeroides.

Table 4. Germination speed index of lettuce seeds submitted to different types of extraction solvents and organs of Alternanthera philoxeroides.

\begin{tabular}{lcc}
\hline \multirow{2}{*}{ Extraction solvents } & \multicolumn{2}{c}{ Germination Speed Index } \\
\cline { 2 - 3 } & \multicolumn{2}{c}{ Source organs } \\
\hline Hexane & Leaf & Stem \\
Ethyl acetate & $26.89 \mathrm{Aa}$ & $26.28 \mathrm{ABa}$ \\
Butanolic & $24.71 \mathrm{Bb}$ & $26.81 \mathrm{Aa}$ \\
Aqueous & $26.36 \mathrm{ABa}$ & $25.72 \mathrm{Ba}$ \\
\hline
\end{tabular}

*Means followed by the capital letters in the column and small ones in the row do not differ statistically by the Tukey test at the level of $5 \%$ of error probability.

Table 5. Germination speed index of lettuce seeds submitted to different concentrations and types of extracts of Alternanthera philoxeroides.

\begin{tabular}{|c|c|c|c|c|}
\hline \multirow{3}{*}{$\begin{array}{l}\text { Concentration of the } \\
\text { extracts }\left(\mathrm{mg} \mathrm{mL}^{-1}\right)\end{array}$} & \multicolumn{4}{|c|}{ Germination speed index } \\
\hline & \multicolumn{4}{|c|}{ Extraction solvents } \\
\hline & Hexane & Ethyl acetate & Butanolic & Aqueous \\
\hline 0 & $28.62 \mathrm{Aa}$ & $28.62 \mathrm{Aa}$ & $28.62 \mathrm{Aa}$ & $28.62 \mathrm{Aa}$ \\
\hline 1 & $27.25 \mathrm{Ba}$ & 26.07 Bab & 26.25 Bab & 25.51 Bab \\
\hline 2 & $25.92 \mathrm{Bb}$ & $25.88 \mathrm{Bb}$ & $25.55 \mathrm{Bb}$ & $24.87 \mathrm{Bb}$ \\
\hline 3 & $24.56 \mathrm{Ca}$ & $22.46 \mathrm{Cb}$ & $23.71 \mathrm{Cab}$ & $23.41 \mathrm{Cab}$ \\
\hline
\end{tabular}

*Means followed by the same capital letters in the column and small ones in the row do not differ statistically by the Tukey test at the level of $5 \%$ of error probability. 
Studies carried out with Artemisia annua L., evaluating the allelopathic effect on the germination and initial development of lettuce seedlings found that the plants root system is the most sensitive to the action of allelochemicals, because their elongation depends on cell division, and if inhibited, it affects their normal development (Magiero et al. 2009).

For the variable radicle length, significant interaction between the organs and the extraction solvent was also found, of which the ethyl acetate extract obtained from the leaves and butanolic obtained from the stem were the ones which most negatively interfered in radicle growth (table 7).

For the variable radicle length, significant interaction between the organs and the extraction solvents was also found, of which the ethyl acetate extract obtained from the leaves and butanolic obtained from the stem were the ones which the most interfered negatively on radicle length (table 7).

In a work conducted by Cândido et al. (2010), to verify the allelopathic potential of invasive leached plant leaves such as Amaranthus viridis
(Amarantaceae) and Leonurus sibiricus, it was demonstrated that extracts of these plants, caused inhibition of germination percentage $(>40 \%)$ and root growth ( $\geq 70 \%$ ) of lettuce seeds, furthermore, these authors also found that the biometric test (radicle measurement) is more sensitive in determining the allelopathic effects and can be favored by the physical contact of the root with the filter paper substrate used.

Antibacterial activity - The extracts of A. philoxeroides were not capable of inhibiting the growth of reference strains, Bacillus cereus, Staphylococcus aureus (ATCC 25923), Bacillus subtilis, Pseudomonas aeruginosa (ATCC 9027) and Escherichia coli (ATCC 8739). These results are somewhat unexpected as many metabolites present in this species have been identified and phenolic compounds, of course, effective against pathogenic microorganisms are widely distributed in A. philoxeroides (Fang et al. 2009).

Caetano et al. (2002) analyzed the crude extract of $A$. brasiliana as to its antimicrobial activity against strains of S. aureus (ATCC 6538 and ATCC 9144) and $S$. aureus hospital isolates (methicillin-resistant

Table 6. Length of the radicles of lettuce seeds submitted to different concentrations and types of extracts of Alternanthera philoxeroides

\begin{tabular}{ccccc}
\hline \multirow{2}{*}{$\begin{array}{c}\text { Concentration of the } \\
\text { extracts }\left(\mathrm{mg} \mathrm{mL}^{-1}\right)\end{array}$} & \multicolumn{3}{c}{ Radicle length $(\mathrm{cm})$} \\
\cline { 2 - 5 } & Hexane & Ethyl acetate & Butanolic & Aqueous \\
\cline { 2 - 5 } & $2.3 \mathrm{Aa}$ & $2.3 \mathrm{Aa}$ & $2.3 \mathrm{Aa}$ & $2.3 \mathrm{Aa}$ \\
1 & $2.1 \mathrm{Ba}$ & $1.4 \mathrm{Bb}$ & $1.3 \mathrm{Bb}$ & $1.5 \mathrm{Bb}$ \\
2 & $1.9 \mathrm{Ca}$ & $1.3 \mathrm{Bb}$ & $1.1 \mathrm{Cc}$ & $1.3 \mathrm{BCb}$ \\
3 & $1.5 \mathrm{Ca}$ & $1.0 \mathrm{Cc}$ & $1.0 \mathrm{Cc}$ & $1.2 \mathrm{Cb}$ \\
\hline
\end{tabular}

*Means followed by the same capital letters in the column and small ones in the row do not differ statistically by the Tukey test at the level of $5 \%$ of error probability.

Table 7. Length of the radicles of lettuce seeds submitted to different types of extraction solvents and organs of Alternanthera philoxeroides.

\begin{tabular}{lcc}
\hline \multirow{2}{*}{ Extraction solvents } & \multicolumn{2}{c}{ Radicle length $(\mathrm{cm})$} \\
\cline { 2 - 3 } & \multicolumn{2}{c}{ Source organs } \\
Hexane & Leaf & Stem \\
Ethyl acetate & $1.9 \mathrm{Aa}$ & $1.9 \mathrm{Aa}$ \\
Butanolic & $1.4 \mathrm{Cb}$ & $1.7 \mathrm{Ba}$ \\
Aqueous & $1.5 \mathrm{BCa}$ & $1.4 \mathrm{Ca}$ \\
\hline
\end{tabular}

*Means followed by the same capital letters in the column and small ones in the rows do not differ statistically by the Tukey test at the level of $5 \%$ of error probability. 
and non-resistant) and the extract showed an activity quite similar to tetracycline hydrochloride used as a standard.

It was also recorded antimicrobial activity of crude extracts of $A$. maritima, especially versus Gram-positive bacteria (S. aureus (ATCC6538), Streptococcus mutans (ATCC 25175) and the ethanol and hexane extracts of the aerial parts of $A$. maritima showed some inhibition against Gram-negative bacteria such as E. coli (ATCC 10538) and E. coli $(26.1 \mathrm{ec})$. The authors further suggest that these extracts can be utilized as a natural antimicrobial additive in cosmetics or in food industry or otherwise help in synthesis of new drugs (Salvador et al. 2004).

The absence of antimicrobial activity observed in this work for the organic extracts (hexane, methylene chloride, ethyl acetate, butanolic) and inorganic (crude extract) instigate the conducting of new tests with other species of indicator organisms, other extraction solvents and still other concentrations of extracts in order to obtain a better definition of antibacterial activity profile of the species $A$. philoxeroides.

It is concluded that all the organic and inorganic extracts studied here in present allelopathic effect because they act by decreasing the germination speed and radicle length of lettuce seeds. Nevertheless, there is no antibacterial activity in the extracts of A. philoxeroides against the reference strains used in this experiment.

\section{Literature cited}

Anese, S., Wandscherer, A.C.D., Martinazzo, E.G., Pastorini, L.H. 2007. Atividade alelopática de Ateleia glazioveana Baill (timbó) sobre Lactuta sativa L. (alface). Revista Brasileira de Biociências 5: 147-149.

Brochado, C.O., Almeida, A.P., Barreto, B.P., Costa, L.P., Ribeiro, L.S., Pereira, R.L.C., GonçalvesKoatz, V.L., Costa, S.S. 2003. Flavonol robinobiosides and rutinosides from Alternanthera brasiliana (Amaranthaceae) and their effects on lymphocyte proliferation in vitro. Journal of the Brazilian Chemical Society 14: 449-451.

Caetano, N., Saraiva, A., Pereira, R., Carvalho, D., Pimentel, M.C.B., Maia, M.B.S. 2002. Determinação de atividade antimicrobiana de extratos de plantas de uso popular como anti-inflamatório. Revista Brasileira de Farmacognosia 12: 132-135.

Cândido, A.C.S., Dias, A.C.R., Serra, A.P., Chritoffoleti, P.J., Scalon, S.P.Q., Pereira, M.T.L. 2010. Potencial alelopático de lixiviados das folhas de plantas invasoras pelo método sanduiche. Revista Brasileira de Biociências 8: 268-272.
Cechinel, F.V., Yunes, R.A. 1998. Estratégias para a obtenção de compostos farmacologicamente ativos a partir de plantas medicinais. Química Nova 21: 99-105.

Cunico, M.M., Miguel, O.G., Miguel, M.D., Auer, C.G., Monache, F.D. 2006. Potencial antimicrobiano e alelopático das amidas isoladas do extrato das raízes de Ottonia martiana Miq. Química Nova 29: 746-749.

Dias, D.A., Urban, S., Roessner, U.A. 2012. Historical overview of natural products in drug discovery. Metabolites 2: 303-336.

Dias, G., Zucoloto, M., Caldas, Z.M. 2008. Estresse oxidativo em células vegetais mediante aleloquímicos, Revista Facultad Nacional Agronomia 61: 4237-4247.

Dias, J.F.G., Miguel, M.D. 2005. Allelophatic applied study from aster lanceolatus, willd. Visão Acadêmica 6: $25-27$.

Dias, J.F.G., Miguel, O.G., Miguel, M.D. 2007. Cromatografia gasosa e avaliação da atividade alelopática das frações hexano, diclorometano e acetato de etila de Aster lanceolatus willd. (Asteraceae). Visão Acadêmica 8: 11-19.

Duarte, M.C.T. 2006. Atividade Antimicrobiana de Plantas Medicinais e Aromáticas utilizadas no Brasil. Revista Multiciência 7: 10-14.

Eldeen, I.M.S., Elgorashi, E.E., Mulholland, D.A., Van Staden, J., Anolignan, B. 2006. A bioactive compound from the roots of Terminalia sericea. Journal of Ethnopharmacology 103: 135-138.

Facundo, V.A., Azevedo, M.S., Rodrigues, R.V., Nascimento, L.F.D., Militão, J.S., da Silva, G.V., Braz-Filho, R. 2012. Chemical constituents from three medicinal plants: Piper renitens, Siparuna guianensis and Alternanthera brasiliana. Revista Brasileira de Farmacognosia 22: 1134-1139.

Fang, J.B., Duan, H.Q., Zhang, Y.W., Yoshihisa, T. 2009. Cytotoxic triterpene saponins from Alternanthera philoxeroides. Journal Asian Natural Product Research 11: 261-266.

Ferreira, A.G., Aquila, M.E.A. 2000. Alelopatia: Uma área emergente da ecofisiologia. Revista Brasileira de Fisiologia Vegetal 12: 175-204.

Ferreira, A.G., Borghetti, F. 2004. Germinação: do básico ao aplicado. Artmed, Porto Alegre.

Guerra, M.P., Nodari, R.O. 2001. Biodiversidade: aspectos biológicos, geográficos, legais e éticos. In: C.M.O. Simões, E.P. Schenkel, G. Gosmann, J.C.P. Mello, L.A. Mentz, P.R. Petrovick. Farmacognosia: da planta ao medicamento, Universidade Federal de Santa Catarina, Florianópolis.

González, R.H., Mederos, M., Sosa, H.I. 2002. Efectos alelopáticos de restos de diferentes especies de plantas medicinales sobre la albahaca (Ocimum basilicum L.) en condiciones de laboratorio. Revista Cubana Plantas Medicinais 7: 1-7. 
Jalapure, S.S., Grawal, N., Patil, M.B., Chimkode, R., Tripathi, A. 2008. Antimicrobial and wound healing activities of leaves of Alternanthera sessilis Linn. International Journal of Green Pharmacy 2: 140-142.

Jandrey, H.C.M., Onofre, S.B. 2009. Atividade antimicrobiana de extratos etanólicos de Alternanthera brasiliana (L.) O. Kunt. (amaranthaceae) sobre bactérias patogênicas. Revista Biologia da Saúde Unisep 31: 51-57.

Kannan, M., Chandran, R.P., Manju, S. 2014. Preliminary phytochemical and antibacterial studies on leaf extracts of Alternanthera brasiliana (L.) Kuntze. International Journal Pharmacy and Pharmaceutical Sciences 6: 626-628.

Machado, A., Conceição, A.R. 2002. Programa Estatístico WinStat - Sistema de Análise Estatístico para Windows. Versão 2.0. Pelotas, Universidade Federal de Pelotas, Pelotas.

Mairesse, L.A.S., Costa, C.E., Farias, J.R.F.R. 2007. A Bioatividade de extratos vegetais sobre alface (Lactuca sativa L.). Revista da Faculdade de Zootecnia, Veterinária e Agronomia 14: 1-12.

Magiero, E.C., Assmann, L.M., Marchese, J.A., Capelin, D., Paladin, M.V., Trezzi, M.M. 2009. Allelopathic effect of Artemisia annua L. on the germination and initial development of lettuce (Lactuca sativa L.) and wild poinsettia (Euphorbia heterophylla L.) seedlings. Revista Brasileira de Plantas Medicinais 11: 317-324.

MAPA - Ministério da Agricultura, Pecuária e Abastecimento. 2009. Regras para análise de sementes. (Mapa/ACS), Brasília.
Mcchesney, J.D., Venkataraman , S.K., Henri, J.T. 2007. Plant natural products: Back to the future or into extinction? Phytochemistry 68: 2015-2022.

Nascimento, P.F.C., Nascimento, A.C., Rodrigues, C.S., Antoniolli, A.R., Santos, P.O., Barbosa, J., Trindade, R.C. 2007. Atividade antimicrobiana dos óleos essenciais: uma abordagem multifatorial dos métodos. Revista brasileira de Farmacognosia 17: 108-113.

Pinto, A.C., Silva, D.H.S., Bolzani, V.S., Lopes, N.P., Epifanio, R.A. 2002. Produtos naturais: atualidade, desafios e Perspectivas. Química Nova 25: 45-61.

Salvador, M.J., Dias, D.A. 2004. Flavone C-glycosides from Alternanthera maritima (Mart.) St. Hil. (Amaranthaceae). Biochemical Systematics and Ecology 32: 107-110.

Salvador, M.J., Zucchi, O., Araújo, L.D., Candido, R.C., Ito, I.Y., Dias, D.A. 2004. In vitro antimicrobial activity of crude extracts and isolated constituents of Alternanthera maritima (Amaranthaceae). Pharmaceutical Biology 42: 138-148.

Sampietro,D.A. 2001. Alelopatía: Concepto, características, metodología de estudio e importância. Universidad Nacional del Nordeste, Corrientes.

Sousa, F.C., Melo, C.T.V., Citó, C.O.M., Cavalcante, F.H., Vasconcelos, S.M.M., Fonteles, M.M.F., Viana, G.S.S. 2008. Plantas medicinais e seus constituintes bioativos: Uma revisão da bioatividade e potenciais benefícios nos distúrbios da ansiedade em modelos animais. Revista Brasileira de Farmacognosia 18: 642-654. 